\title{
THE NEED FOR SPECIAL, SIMPLIFIED MECHANICS' LIEN ACTS APPLICABLE TO HOME CONSTRUCTION
}

\author{
Bettin Stalling*
}

There is evident need in this country for more small homes. Yet our present mechanics' lien ${ }^{1}$ laws constitute one of the principal impediments to the repeated efforts to encourage and promote the individual ownership of homes. The origin and operating effect of these laws will be discussed from this viewpoint.

The first mechanics' lien law in this country was adopted by Maryland in I79r." The underlying purpose of the statute was to aid in building up the country by attracting employees to the building field. It was urged that the establishment of a right in laborers and building-trade mechanics to a lien against the improved real estate for wages which might be unpaid would result in making available a needed supply of skilled man-power. When the early statutes were enacted, agriculture was the principal pursuit and neither effective labor organizations nor trade associations of the building industry existed. It is understandable therefore that, in response to the needs of the time, legislation would be urged and enacted which provided incentives to engage in the building field.

But today, since there is no dearth of employees in this field, legislation enacted on the labor-scarcity theory serves no present need. The situation, if anything, is the exact reverse of that obtaining when the original mechanics' lien statutes were adopted. The new problem of today is how to provide this field with employment by favorable legislation which will attract people to home ownership.

The view seems to have gained general acceptance in this country, whether rightly or wrongly, that owning a home is uneconomic and not worth the candle. Certain obvious factors have contributed to this opinion. It will be admitted by everyone that the act of building a home has evolved into such a complicated process as to make the task extremely burdensome and difficult. The effect, by-and-large, of the mechanics' lien laws, from a national viewpoint, has contributed to making the task also financially hazardous. This arises from the potential double liability which these

- LL.B., 1923, University of Chicago. Head Attorney in Charge of Reconditioning Section, Scrvicing Division, Legal Department, Home Owners' Loan Corporation. Member of Illinois Bar, practicing in Chicago from 1924 to 1933 . Attorney member and Chairman of Chicago N.R.A. Compliance Board No. 2, I933.

${ }^{1}$ For the purpose of this article, this term will be used to include material-men's liens.

${ }^{2}$ Md. Acts I79I, c. 45 . 
acts impose on the owner if he has not strictly complied with the technical provisions governing the making of payments due and to become due under the particular construction then in progress.

Furthermore, the mechanics' lien laws, because of their technical and cumbersome procedure, cannot escape responsibility for having generally and unwittingly contributed to the unwholesome growth, in the small construction industry, of inefficient and loose practices that are as unnecessary and unsound as they are hampering and unbusinesslike. This condition has developed out of the gradual amending of these acts so as to grant liens, of varying extent and under varying conditions, to practically every segment composing the construction industry-including contractors, subcontractors, material dealers, laborers, artisans, architects, landscape architects, engineers, surveyors-for the labor, services, or materials furnished or contracted to be furnished for the particular improvement.

\section{Impediments Placed by Mechanics' Lien Laws on Home Construction}

A detailed discussion of a typical mechanics' lien act would be so technical and tedious as to be confusing. That the mechanics' lien laws work badly for small home construction was the conclusion of an article which the writer prepared for the April, $193^{8}$ issue of the Federal Home Loan Bank Review. Some of the points and conclusions of this article are so directly pertinent that they will be quoted: ${ }^{3}$

"In actual practice, these laws have created a number of problems in the field of housing. The effect of existing laws can be clearly shown by discussing the three parts of a typical mechanics' lien statute which most vitally affect (a) the owner; (b) the contractor and parties such as subcontractors and material dealers working with him; and (c) the lending institution. The three parts relate to $(x)$ the right to, and the extent and duration of, a lien; (2) the priority of liens; and (3) the owner's responsibility and risk in making payment to the general contractor.

"The Right to, and the Extent and Duration of, a Lien-The statutes are not uniform in specifying who shall be entitled to a lien nor under what conditions, although practically all statutes give a lien to laborers. However, in spite of the many variations existing between different States, it may be said generally that present statutes permit a claimant to effect a cloud on the title to real estate with comparative facility. Moreover, some statutes permit an unreasonable period to elapse without requiring the claimant to have his claim adjudicated. The cost of filing a claim is nominal, and it is easy and cheap for a disgruntled and even undeserving claimant to effect a cloud on title. This furnishes the claimant with a strong lever to force unfair settlements from the owner, particularly if the owner needs to clear title in order to mortgage or transfer the property.

"Every State prescribes the place and method for filing a lien; and the period fixed by statute for filing vvaries from 30 days to six months. Once filed, stipulated statutory conditions governing the foreclosure and enforcement of the claim must be complied with. Otherwise, a claim loses its legal vitality. The claimant must commence foreclosure at any time within six years in three States, two years in six States, and one year in I6 States, and within periods ranging downward to a minimum of 60 days in other States.

"There is a long continuing risk under certain circumstances in many States that mechanies' liens may take precedence over liens securing a mortgage indebtedness. Con-

'Stalling, Mechanics' Lien Laws as They Exist Today (1938) 4 F. H. L. B. Rev. 232-234. 
sequently, this has the effect of increasing the financing cost of reconditioning or new construction because conservative mortgage-lending institutions charging low interest rates find that they must either forego this type of lending entirely or else establish extensive service facilities to make the necessary checks to protect against such liens. The cost of this service is necessarily passed on to the owner in the nature of loan service charges. This increased probability of liens also operates to increase the cost of title examination as well as the cost of title insurance.

“Priority of Liens-In every State, mechanies' liens take priority over subsequent encumbrances; in seven or more States such liens, under varying conditions, even take priority over previously existing encumbrances as, for example, Oregon, where a mechanics' lien for improvements erected on the land takes priority over an antecedent mortgage against the land. There are other States which follow a 'severability' doctrine which permits the antecedent lien against the land to take priority as to the land, whereas the mechanics' lien takes priority as to the improvements only. In States following this view the improvements may be severed and removed when no damage to the land will result.

"The general lack of uniformity in this vital phase of the mechanics' lien laws constitute a manifest danger from the lenders' point of view. The foregoing represent only the main theories as to lien priority. Many States have adapted these theories by introducing variations to meet given local conditions.

"Regulation of Payments by OWNer to Contractor-In about three-fourths of the States the owner pays the general contractor at his peril. In these States, notwithstanding the fact that the general contractor may be the only person with whom the owner had a direct contract for the construction, and even though the owner may not know the names of potential claimants and has not been notified of any claims for liens by unpaid eligible claimants, the owner may nevertheless have to make double payment unless he has taken the precautionary measures prescribed by the statutes.

"In most of the remaining 25 per cent of the States, if the owner makes payments to the contractor before he receives notice of a claim for lien by an unpaid and otherwise eligible claimant, he is protected to the extent of such prior payment. However, a duty is imposed upon him to apply the unpaid balance as the statute prescribes. In some States, there is only one way the owner can be certain of protection from loss. He must withhold payment to the general contractor until the statutory period for filing (not foreclosing) liens has expired so that he may ascertain whether liens will arise.

"Thus many statutes place a premium on delayed payments. Under such circumstances, payment is never a simple task. Moreover, the statutory provisions governing payment are usually wordy, technical, and so involved that an owner lacking experience in such matters may be wholly at sea. Building a home is an enterprise undertaken by the average citizen but once in a lifetime and the ordinary inexperienced and uniformed person, especially the prospective owner of a small home, is frequently put to the expense of engaging an attorney or other competent agent before he can proceed in what should be a reasonably simple and expeditious transaction-namely, the payment with safety, of the cost of constructing his own home.

"In a great many States the mechanics' lien laws impose upon the owner the responsibility of seeing to it that his general contractor and others discharge the debts incurred by them in building or repairing his home. This condition makes for the continuance of an unsound credit system at the expense of the owner, and to the detriment of contractors who endeavor to operate on an efficient and business-like basis. In the small home field a general credit laxity to contractors and others prevails-a condition due in large part to the fact that material dealers and other creditors realize that the particular improvement can 
be made available, through the medium of the mechanics' lien law, to secure the credit extended.

"Under such circumstances, there is but little need for a contractor to manage his business with efficiency in order to acquire and maintain a credit standing. The resultant waste is often reflected in higher construction costs or what amounts to the same thing, construction of a shoddy and unsound character."

To summarize, the article concludes that the mechanics' lien laws, as they exist today:

"r. add to the costs of construction and financing;

"2. discourage lending for reconditioning and new construction;

"3. increase tendencies to 'jerry-building";

"4. contribute to the expense of title examination and title insurance."

The Need for a Law Specifically Adapted to Home Construction

If the mechanics' lien laws have the foregoing result, then truly they are in need of re-thinking. To the extent these laws lack for practicability they are a failure irrespective of how consistent they may be from the standpoint of abstract legal principles and reasoning. But even from a strictly legal viewpoint alone, they have long been the source of much confusion and uncertainty, and as far back as 1877 one jurist declared that "probably no subject has been more fruitful of conflicting authority than the statutes conferring mechanics" liens." 4 The complete lack of uniformity in the statutes and the conflicting judicial decisions have produced such general dissatisfaction that in 1924 the aid of the Department of Commerce was sought by various industrial leaders and trade associations. In response, Mr. Herbert Hoover, as Secretary of Commerce, appointed a Standard Mechanics' Lien Act Committee to consider the question and to draft a Uniform Mechanics' Lien Act. The Committee, in cooperation with a special Committee of the National Conference of Commissioners on Uniform State Laws, after eight years of extensive study and annual public hearings, concluded its efforts in December, I932.5 'The Uniform Mechanics' Lien Act proposed by the Committee has since been endorsed by the American Bar Association.

That it would require so long a time for the Committee to formulate a uniform act is not as surprising as the fact that one was finally agreed upon. The construction industry embodies a large number of diversified and antagonistic interests. The diffcult task of creating comprehensive procedure which embraces so many independent steps and elements as are involved in a typical mechanics' lien statute, including the extremely delicate matter of establishing lien priorities, will be all the more realized by a reference to some of the business affiliations of those comprising the Committee: American Federation of Labor; National Builders' Supply Association; Associated General Contractors; United States Building and Loan League; National Association of Builders' Exchanges; National Retail Lumber Dealers' Association; Heating and

\footnotetext{
- Butler, J., in Graham v. MIcLean \& Bennor Machine Co., I Chester Co. Rep. 73, 76 (Pa. 1877):

'For the text of the Act and the commissioners' notes thereon, see 9 UNIF. LAws ANN. (Supp. I937) 147. Florida is the only state to have adopted the Act. Fla. Laws 1935, c. 17097.
} 
Piping Contractors' National Association; American Engineering Council; American Institute of Architects; National Association of Credit Men. Other businesses than those suggested by the foregoing list would be affected by such an act, such as title and abstract companies, bonding companies issuing completion bonds, or servicing companies performing mechanics' lien searches, and many other similar enterprises. Moreover, intermingling every decision and act of the Committee was the ever present necessity that all procedures and rights formulated be practicable and yet not do violence to well-established legal principles.

Space does not permit nor is it the purpose of this article to evaluate the numerous component parts of the proposed Uniform Act. The important question here is whether this Act meets the problems confronting home-ownership and whether its effect will be to encourage the building and owning of a home? If the proposed Uniform Act does not achieve these objectives, is it feasible to propose a new uniform act limited in scope to the construction of individual homes which will achieve them?

It is submitted that the Uniform Act proposed by the Committee will not materially reduce the difficulties which the existing laws impose on home construction and home-ownership. The proposed Act has not dealt with the causes underlying these difficulties; it has but substituted a new procedure molded out of the philosophy of the old. But something more is needed; the need is for a procedure based on a philosophy which rejects the principle that in the field of home construction it is essential for the industry factors to enjoy, at the expense of a home-owning group, a special protection of the extent and character usually granted.

The matter of widespread individual home-ownership is inherently charged with broad and distinct social and economic implications of its own; moreover, home owners as a group have a multiplicity of problems of their own. It is logical that this important group, and the socially desirable endeavor to encourage and promote individual home-ownership, be subjected to appropriate laws. But both the existing mechanics' lien laws and the proposed Uniform Act make no distinctions; they apply with equal force to all types of construction, except perhaps public construction and public works. These acts completely fail to reckon with the wide disparity between the ordinary small home owner, unpracticed in legal complications, and owners of commercial buildings who may with reason be presumed to know the legal requirements and to be equipped with facilities for meeting them in the ordinary course of their business. Thus the same duties and obligations-technical, perilous, and burdensome as they may be-are imposed on the building of the smallest cottage as are imposed upon the building of the Empire State Building.

\section{Reasons Supporting Existing Laws Not Equaliy Applicable to Home Construction}

An inquiry will reveal that the reasons generally advanced in support of the existing mechanics' lien statutes do not apply with equal force to the home construction field as they do to other types of construction. 
There are two principal reasons advanced in support of these statutes:

I. that the building industry by its nature requires special protection; and

2. that mechanics' lien statutes prevent unjust enrichment of the owner at the expense of those who contribute to his home but are not paid.

The first reason, namely, that the building industry by its nature requires special protection, proceeds upon the argument that the industry, as an industry, is necessarily required to extend credit for larger amounts than other types of business, and for a longer term; that in this regard it is denied the protection which other business enjoys from the fact that their credits involve small amounts and are widespread; that contractors, subcontractors, materialmen, and other segments of the building industry might have their entire capital or a substantial part of it tied up in one or two projects under construction and that their business will be seriously imperiled in the absence of special statutory protection; that the foregoing factors combine to make it essential and natural that the building industry have special protection for all types of construction.

Testing the applicability of the above reasoning to the small home construction field, it is pertinent to ask: What, in the construction of an ordinary residence, is the amount of credit risk usually assumed by the various trades involved, and for what period of time is such credit extended? While these elements will vary dependent upon the house in question, nevertheless a fair idea of the amount of the credit can be had by indicating the usual trades involved in ordinary residential construction and showing the percentage cost of the trades designated, including labor and materials, to the total cost of construction. The United States Department of Labor computed these percentages as follows: ${ }^{6}$

$$
\text { Class of Work }
$$

Percentage

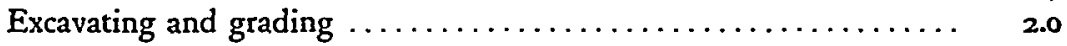

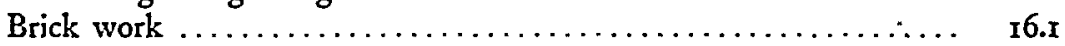

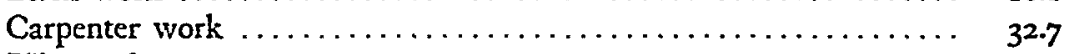

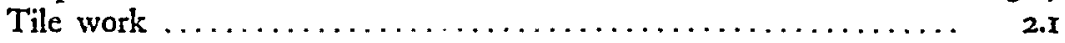

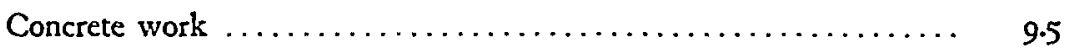

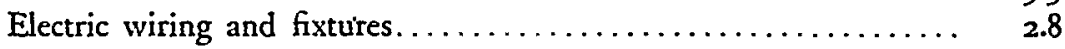

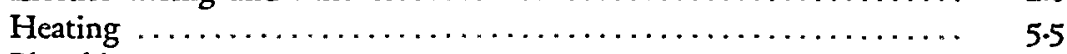

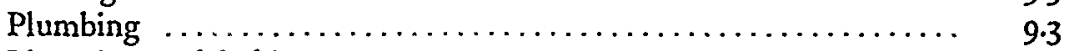

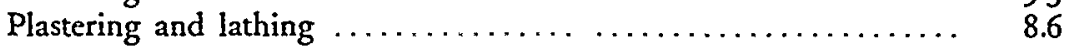

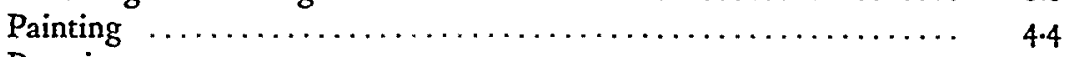

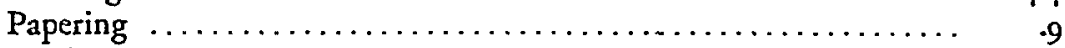

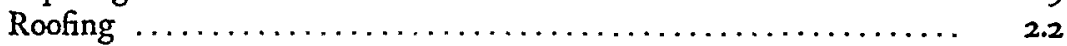

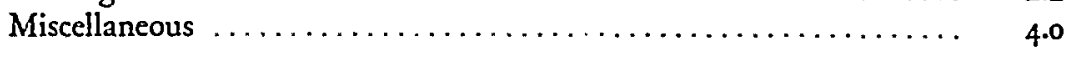

$\frac{4.0}{100.0}$

'U. S. Bureau of Libor Statistics, Buzl. No. 49 (1929) 222. This publication was issued in August, 1929, but the writer has been reliably informed that, while the percentages shown may not be precisely accurate today, nevertheless they are sufficiently accurate for the point at issue. 
Applying the above percentages to a home costing $\$ 6,000.00{ }^{7}$ it is apparent that the amount of credit of the various trades involved is not, in the light of present-day commerce, extraordinary. The duration of the credit is also, in the light of present credit practices, not for an uncommonly long period of time. Assuming that a new uniform act for home construction would grant a lien to the general contractor, and to other persons having direct commitments from the owner, can it be contended that the building industry, in the light of the foregoing figures, will be seriously impaired unless a lien will be had by every person furnishing labor or materials to the particular job even though such person has had no dealing with the owner?

It is the writer's considered opinion that when the acid test is applied, reason number one, forceful and applicable as it may be to larger construction work, does not apply to small home construction with sufficient force to justify the burdens the existing type of statutes place upon small home-ownership.

As to the second reason, that unscrupulous property owners would become unjustly enriched at the expense of other persons, it is submitted that an appropriate statute can be devised which prevents this contingency from arising. A statute granting a right of lien to the general contractor, and to persons having direct commitments from the owner, will prevent unjust enrichment since everyone may thus have his lien provided he has a written agreement with the owner.

\section{Basic Principles of a Uniform Act Applicable to Home Construction}

If the foregoing analysis is sound, then the reasons advanced to support the existing mechanics' lien statutes fail when applied to the small home construction field. This leaves the door open for an appropriate statute applicable and suitable to this type of construction. The important problem in the drafting of such a limited uniform act is the determining of its basic provisions. Some of the possibilities along this line will be considered.

Since the home owner, the lender, and the building industry are the three most important factors affected, a discussion of principles and practical considerations applicable to these three is in order.

From the point of view of a home owner, the chief objections to existing statutes could rèadily be averted by limiting a right of lien to persons to whom the owner is directly and legally committed. It is submitted that the imposition of a potential double liability on the owner to persons with whom he has not dealt is unsound and violates elemental justice. A statute which thus limits the owner's liability would at least enable prompt payments to be made with safety and remove the premium the existing statutes place upon delayed payments-a practice as harmful to the welfare of the building industry as it is objectionable and burdensome to the home owners and lending institutions alike. Further protection to owners could also be

${ }^{7}$ The average cost of owner-residence in this country as a whole is not available. It is believed that the figure given would not be found too far out of line with the average cost, were such information available. 
obtained, and with good supporting reason it is submitted, by conditioning the right to a lien upon certain minimum requirements as to amount. Statutes of this type already exist in several states, for example, Connecticut where no right of lien arises for contracts not exceeding $\$ 10.00$ in amount; ${ }^{8}$ Pennsylvania, $\$ 100.00 ;^{0}$ Delaware, $\$ 25.00 .^{10}$ In Maryland no lien arises unless the amount involved equals or is more than $25 \%$ of the value of the improvements. ${ }^{11}$ Obviously, there exist many methods by which the objections of home owners as a group to the existing statutes, and the burdens which such statutes impose on home-ownership in general, could be ameliorated if not entirely removed without real prejudice to the other affected interests.

In considering the position and needs of the lender, it should be remembered that few homes are built today which are paid for outright. Borrowing today is so general in this field that it may be regarded as a concomitant of construction and home-ownership. The lender usually has a substantial investment in the property and in this regard his position is in many respects similar to that of an owner. Since the existence of adequate lending facilities is a prerequisite to increased home construction, it is essential that the business of home lending be rendered safe and that it be encouraged, if interest rates and the cost of financing-factors which so directly affect the ultimate cost of home-ownership-are to be held to a minimum. It would also be extremely helpful and economical if the permanent loan could, with safety, provide for advances to be made during construction. This would remove the necessity for, and eliminate the waste connected with, the practice in many localities of making two sets of loans-a temporary loan for the construction, and a permanent loan refunding the temporary loan after construction is completed.

It is submitted that a uniform mechanics' lien act limited to small home construction should not only protect an antecedent mortgage against the contingency of a mechanics' lien taking priority to such mortgage (which protection some of the existing statutes deny), but should also protect the lien priority of permanent mortgages which appropriately provide for future advances. A statute of this sort would go a long way to reduce the cost of financing which in turn reduces the ultimate cost of home construction and home-ownership.

As to the position of the factors in the building industry, including contractors, subcontractors, and others who may furnish labor and materials, it is important to keep in mind that a right to a lien is not an elective legal remedy, but an additional remedy. Thus potential lienors, when seeking to establish their lien claims, are not thereby cut off from any of the other legal remedies applicable to the transaction for the collection of debts or otherwise. It is submitted that a uniform statute for home-ownership should provide, in effect, that before an additional legal remedy in the nature of a lien on home property may be invoked, the owner of the property

\footnotetext{
${ }^{3}$ Conn. Gen. Stat. (1930) \$5105.

49 PA. Stat. Ans. (Purdon, I930) $\$ 22$ (limited to alterations and repairs).

${ }^{30}$ Del. Rev. Code (1935) \$3324.

"MD. ANs. CODE (Bagby, 1924) (not applicable to new construction).
} 
must be under some form of commitment to the lienor. A statute embodying this feature would protect the owner from possible double liability to hidden claimants with whom he has had no dealing. At the same time it would afford a reasonable basis and opportunity for the obtaining of liens by those who feel they cannot rely upon the credit responsibility of the general contractor or subcontractor or other person primarily obligated to them in the transaction. It is also believed that a statute embodying the features suggested would screen-out "jerry builders" and would, in the long run, make for a better industry integration and independence.

As to protecting those who ordinarily come within the legal definition of laborers and mechanics, it must be recognized that the statutes today afford very little actual protection to these claimants. This is due to the fact that the statutes are so complicated and technical in their procedure, and that the cost of enforcing a lien is so disproportionate to the usual small amounts which might be owing for wages unpaid, as to render it wholly impracticable for wage claimants to resort to these statutes for relief. It is submitted that much more simpler and effective methods to protect wage earners is needed. An example would be a statute that imposed a duty, under penalty, on the contractor to apply proceeds received first to the payment of laborers and mechanics employed by him on the particular job.

In considering the lien priorities here discussed for the industry factors, the problem remains how best to prevent possible conflict of priorities between lending institutions and the building industry factors. It is submitted that the true relationship between lenders and the building industry is that the business of each is best served by the successful culmination of the undertakings of the other. Each is a business feeder to the other. In the last analysis, the problem resolves itself into a task of finding the simplest and most efficient means to enable the safe and smooth pay-out of funds by the lending institution. While the problem is intricate, it is not insoluble and suggested solutions may be found in some of the statutes governing the pay-out for public construction. Moreover, the task is immediately reduced in size and complexity once the number of potential lien claimants is held to the minimum proposed.

\section{Legislative Advantages of Uniform Act Confined to Home Construction}

Before formulating a proposed uniform act limited to the small home construction field, proponents 'should weigh carefully the problems confronting its adoption. The probabilities of adoption depend upon the extent and character of its support as well as its opposition. Would not the limited character of such an act enhance its chances of adoption?

A uniform mechanics' lien act embracing the whole construction field runs the risk of wide and varied opposition. This, of course, is due to the great number of enterprises affected in the ever broadening field of construction-whether such construction involves drainage and irrigation works, oil wells, manufacturing plants, apartment houses, hotels, churches, cemeteries, skyscrapers or the like. Thus, 
interests which are not concerned with home construction, and which might not be opposed to a proposed act limited to this field, may find it necessary to oppose a comprehensive mechanics' lien act applicable to the whole industry in order to assure defeat of that portion which adversely affects their particular interest. It is significant that the Uniform Mechanics' Lien Act proposed in 1932 has been enacted in only one state. ${ }^{12}$

It is clearly a much more feasible task, and one more likely to succeed, to press for the adoption of a needed uniform mechanics' lien act limited to home construction. Assuming that such an act can make for a better balancing of the rights and obligations of the factors involved in this special field, it can be expected that the task will attract the immediate support of many enterprises now engaged in promoting and encouraging the individual ownership of homes.

In summation, it is the writer's opinion that the lien laws, taken collectively, do not serve present-day needs in the field of home construction; that the proposed Uniform Mechanics' Lien Act of the Standard Committee does not meet these needs; and that a new uniform act giving effect to the suggested basic considerations and limited to the field of home construction is logical, legal, and capable of enactment.

\footnotetext{
${ }^{2}$ See note 5, supra.
} 